\title{
Recycled ceramic composite for automobile brake pad application
}

\author{
${ }^{1}$ Johnson O. Agunsoye, ${ }^{1,2}$ Sefiu. A. Bello, ${ }^{1}$ Adeola A. Bamigbaiye, \\ ${ }^{1}$ Kayode A. Odunmosu, ${ }^{1}$ Isaac O. Akinboye \\ ${ }^{1}$ Department of Metallurgical and Materials Engineering, University of Lagos Nigeria \\ ${ }^{2}$ Department of Materials Science and Engineering, Kwara State University, Malete, \\ Nigeria \\ E-mail: adekunle_b@yahoo.com or sefiu.bello@kwasu.edu.ng
}

Received: March 20, 2017

\begin{abstract}
Ceramic tile/steel slag-graphite-Arabic gum composite has been developed using conventional casting techniques for brake pad applications. Chemical properties of the phases present in the matrix of the developed composite were examined using X-ray diffractometer. Spatial configuration of the phases was viewed using Scanning Electron Microscope. Wear and thermal properties of the developed composite were also investigated. Correlation between the properties of the developed composite and the commercial grade brake pads were made. Results showed partial homogenity of the second phase particle within the ceramic matrix. The developed composite brake pad showed a better friction property than the commercial grade brake pads up to $200 \mathrm{~s}$ while above this duration, the reverse was the case. The developed composite brake displayed lower wear rates and better thermal stability than the commercial grades implying optimum combination of good wear resistance, friction property and thermal stability up to $200 \mathrm{~s}$. Since brake application while driving is an intermittent short span process ( $<3$ minutes), the developed composite could serve as a replacement for asbestos brake pad for automobile applications.
\end{abstract}

Key words: tile, phases, correlation, replacement, commercial brake pad.

\section{Introduction}

Over the years, improvement in braking systems has been one of top priorities in the automobile industries. Brake pads are vital components of braking system for all categories of vehicles that are equipped with brake discs made of steel backing plates with friction material attached to the surface facing the brake disc [1]. Friction brakes decelerate a vehicle by transforming the kinetic energy of the vehicle to heat via friction and dissipating the heat to the surroundings [2]. Until the late 1960's, most cars used drum brakes on all 
four wheels. The pads for the drum brakes consisted of resins and asbestos as well as a variety of other materials to help improve braking and wear. Later on, automobile manufacturers began to incorporate disc brakes, especially for larger motor vehicles, because they had better braking performances. The Federal Motor Vehicle Safety Standard 105, which required more stringent braking conditiots, helped expedite the transition to disc front - drum rear braking systems [2,3]. Presently, disc brakes system has gained popularity because it dissipates heat and reduces the effect of wear better than drum brakes. Generally, materials used for brake linings include metallic friction materials ( $\mathrm{Fe}$ and $\mathrm{Fe}-\mathrm{Cu}$ oxides), lubricants (graphite and Fe-Sb-Mo-Sn-Mn sulphides) and mineral fibers (barite, calcite, zircon and Al-silicates) used as fillers [3]. Brake pads traditionally consist of asbestos fibers embedded in a polymer matrix along with several other ingredients. Due to its carcinogenic nature, the use of asbestos fibre in brake pad systems is no longer acceptable. This development has necessitated researchers to shift attention to the development of new asbestos-free brake pads from agricultural and industrial waste products [4].

Researchers all over the world are currently exploring alternatives to existing brake pads due to the environmental and health implications. Lately, agricultural residues or wastes are now emerging as inexpensive filler materials that can be used for the development of commercially viable composite materials. Agricultural wastes such as palm kernel shell, coconut shell, periwinkle shell, banana peel, egg shell, maize husk, cocoa bean shells and bagasse among others, have been used by different researchers as particulate reinforcement for the development of eco-friendly brake pads The results obtained from microstructural and mechanical (hardness, compressive, tensile and wear tests) characterizations showed that they could be effectively used as a replacement for asbestos materials in automotive brake pad manufacture and, unlike asbestos based brake pads, the developed composite brake pad is eco-friendly without any known health hazards associated with it [5-10].

Industrial wastes such as slags are generated in significant quantities as waste material or by-product from steel industries. They usually contain considerable quantities of valuable metals and materials. Converting these solid wastes from one form to another to be reused either by the same production unit or in different applications are very much essential not only for conserving metals and mineral resources but also for protecting the environment [11]. Moreover, the increasing accumulation of industrial waste is a major environmental challenge which has led to the formulation of different environmental laws in recent years. These regulations have compelled engineering sectors to look for ways of harnessing these waste products to develop low cost composite materials with environmental acceptability $[12,13]$. Industrial waste such as ceramic oxide is a type of waste generated from the ceramic industry and from every day use of ceramic materials. These wastes are still yet to be efficiently and economically harnessed in Nigeria, creating a need to explore extensively the possibility of using particulates of agricultural and industrial wastes as reinforcement in the manufacture of brake pads. Thus, taking advantage of the Federal Government of Nigeria local content policy and increasing foreign exchange savings.

The study seeks to compare the properties of the developed composite brake pad using particulate industrial wastes with those of the procured commercial grade brake pad in an attempt to develop an asbestos free brake pad for automobile application. 


\section{Materials and methods}

Epoxy resin (LY 556)/hardener (HT 975) and commercial brake pad (reference) used in this study were bought locally at Ojota and Owode Onirin, Lagos, Nigeria. Steel slag, Gum Arabic, aluminium chips, graphite/bentonite and ceramic tiles were obtained from Steel Making Industries, Lagos; Chemical Shop at Zaria; Mechanical Engineering Workshop, University of Lagos; Nigerian Foundries, Oshodi Lagos and Ongoing Construction Site, Lagos, Nigeria, respectively. The Steel slag, gum Arabic, aluminium chip, graphite and clay were sundried at an average daily temperature of $25^{\circ} \mathrm{C}$ for 10 days. Then, they were crushed manually using a hammer. The broken pieces from each of them were pulverised using a ball mill in accordance with [14]. The pulverised powder was sorted manually using 150 BSS $(106 \mu \mathrm{m})$ mesh sieve. The particulate steel slag (refractory filler), gum Arabic (binder), aluminium chip (abrasive) and graphite (performance) are presented in Plate 1 a-e while Table 1 displays the chemical composition of the ceramic powders obtained from the broken tiles. Weighted quantities of epoxy and hardener were mixed in 2:1. Weighted amounts of other additives (filler, gum Arabic, epoxy/hardener, abrasive, ceramic powder and bentonite) equivalent to various compositions in Figure 1 were added and stirred manually for 10 minutes using a wooden stick. The mulled blend was poured into wooden moulds and clamped (see Plate 1f). The composite bend was allowed to cure at room temperature for 24 hours after which the developed composite brake pads were removed from the mould.

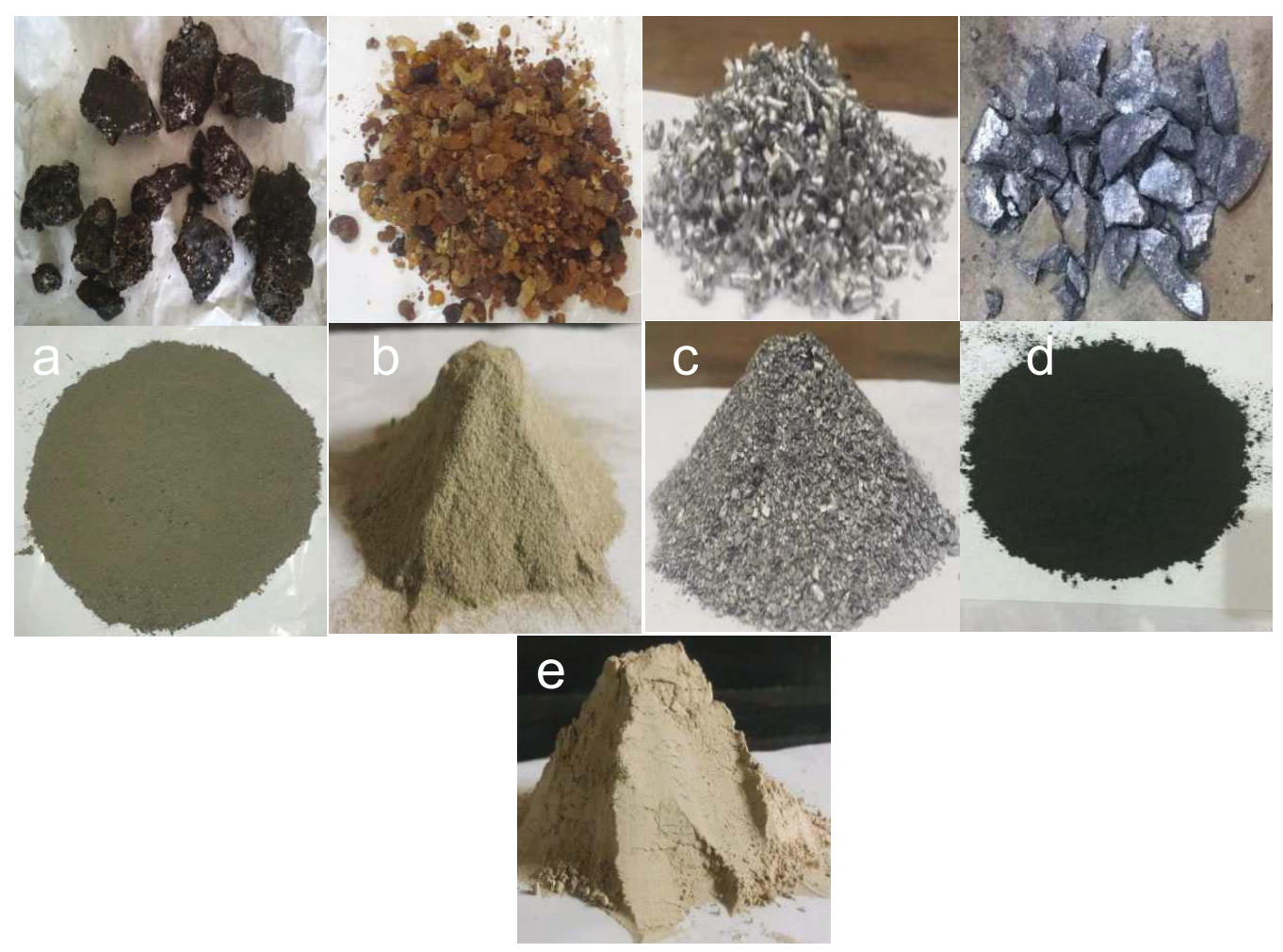

Plate 1.(a-e): 1Materials used for the development of composite brake pad: (a) steel slag (b) gum Arabic (c) aluminium (d) graphite before and after pulverisation (e) ceramic powder. 


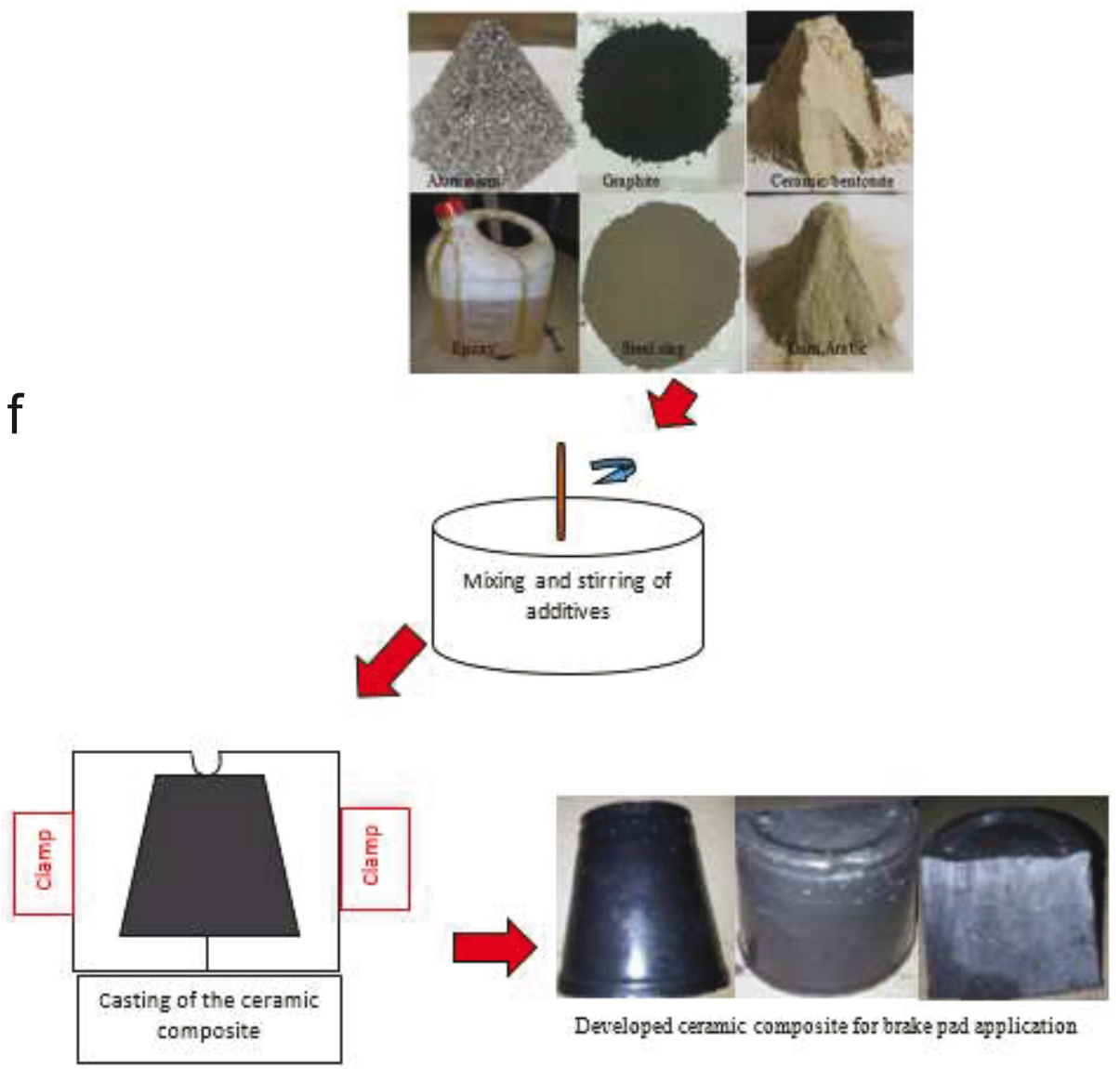

Plate 1.(f): Sequential steps in the composite development.

Table 1: Chemical composition of ceramic particles obtained from broken tiles.

\begin{tabular}{l|llllllllll}
\hline \hline $\mathrm{S} / \mathrm{N}$ & $\mathrm{SiO}_{2}$ & $\mathrm{Al}_{2} 0_{3}$ & $\mathrm{Fe}_{2} 0_{3}$ & $\mathrm{CaO}$ & $\mathrm{Na}_{2} \mathrm{O}$ & $\mathrm{K}_{2} \mathrm{O}$ & $\mathrm{P}_{2} \mathrm{O}_{5}$ & $\mathrm{TiO}_{2}$ & $\mathrm{MgO}$ & $\mathrm{PF}$ \\
\hline$\%$ & 62.36 & 19.20 & 2.51 & 1.85 & 0.23 & 1.80 & 0.05 & 0.81 & 2.15 & 7.1 \\
\hline \hline
\end{tabular}

The microstructural and elemental analysis was carried out using JEOL Scanning Electron Microscope (MODEL: JSM-6510) operated at an accelerating voltage of $2.0 \mathrm{kV}$. X-Ray Diffractometer was also used to identify the phases present. The analysis was done in the $2 \theta$ range between $8-90^{\circ} \mathrm{C}$. Thermal stability of the sample was measured in terms of global mass loss using a TA instrument TGA Q50 thermogravimetric analyser. The test was performed in an inert atmosphere start from $25^{\circ} \mathrm{C}$ to $1000^{\circ} \mathrm{C}$ at a heating rate of $10^{\circ} \mathrm{C} / \mathrm{min}$. The wear rate for the sample was measured with CETR UMT-2 Tribometer at load varying from 25 to $40 \mathrm{~N}$ at $5 \mathrm{~N}$ interval with sliding speed and distance of $2 \mathrm{~m} / \mathrm{s}$ and of $2 \mathrm{~m}$, respectively, using tungsten carbide ball. Frictional force at the sliding interface was measured using a strain gauge while the wear rate was determined by weighing the specimen before and after each test. The formula used to convert the weight loss into wear rate is:

$$
\text { Wear rate }=\frac{\Delta W}{S \cdot A}
$$


where $\Delta W$ is the weight difference of the sample before and after the test in $\mathrm{mg}, S$ is the total sliding distance $(\mathrm{m})$ and $A$ is the applied load $(\mathrm{N})$.

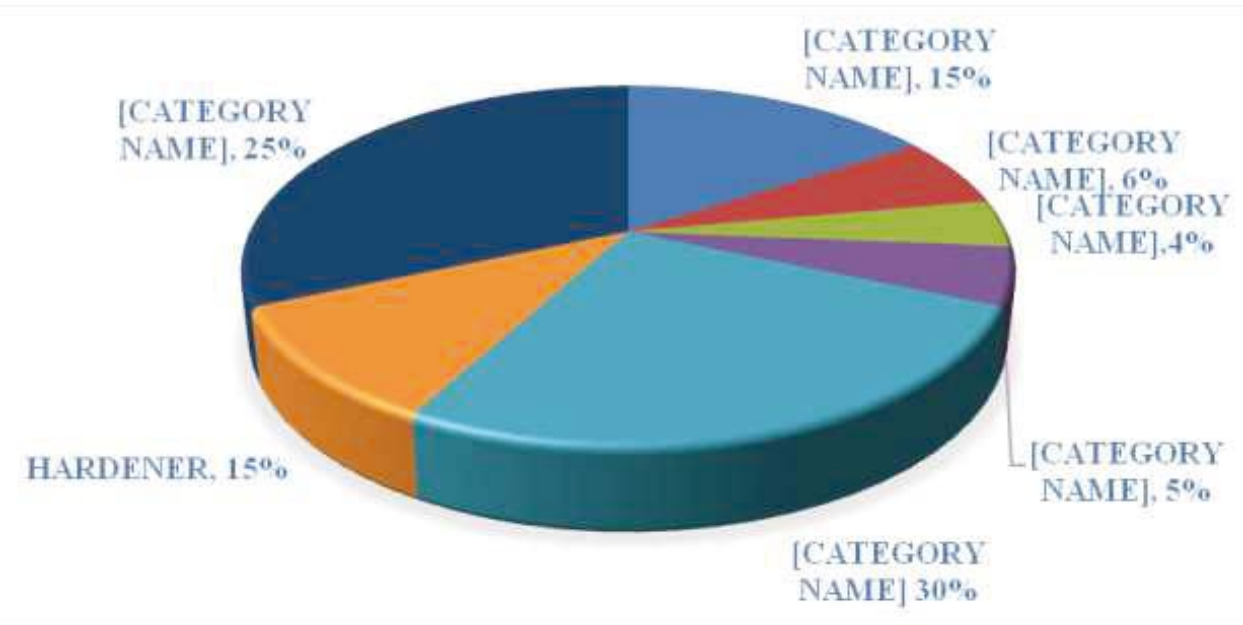

Figure 1: Formulation of the various categories of elements used for the developed brake pad.

\section{Results and discussion}

\subsection{Friction and wear resistance of the developed brake pad compos- ites}

The friction coefficient $(C o F)$ of the commercial sample was compared with the developed composite brake pad as a function of increasing time (see Figure $2(a-b)$ ). An increasing-steady-state-decreasing pattern was observed in the profile of the $C o F$ with time. The developed composite brake pad exhibited better friction property $(0.06 \mu)$ than the procured commercial grade brake pad $(0.033)$ up to $200 \mathrm{~s}$. Beyond $200 \mathrm{~s}$, there was an improvement in the friction property of the procured commercial grade brake. This justified better friction performance of the commercial grade than the developed composite brake pad within this time frame. The possible explanation for degradation in the friction performance/property of the developed composite brake pad above $200 \mathrm{~s}$ could be linked to its inability to withstand increasing heating energy generated as the period of investigation increased. Since heat generation due to surfaces in contact in the wear investigation is analogous to the contact of the brake pad with a rotor on brake application, continual brake application beyond 3 minutes (180 s) can lead to failure of the developed composite brake pad. Furthermore, up to 3 minutes the developed composite is more reliable for brake pad application than the procured commercial grade. Production technique is one of the key factors affecting properties of materials [15]. Typically, a brake pad is fabricated under pressure with a press. The conventional casting technique used in this study for the development of composite brake pad without any compaction may influence the structural integrity of the developed composite brake pad and lead to poor friction property above $200 \mathrm{~s}$. Since another prerequisite for the brake system is an excellent resistance to wear, 
the wear behaviour of both the commercial grade and the developed composite brake pad were investigated under increasing load and time to ascertain if the slight reduction in $C o F$ will translate to greater advantage with respect to wear resistance. The initial increase in the loss of material may be due to rupture of the uneven surfaces of the virgin brake pad resulting in a third body between the interfaces. The presence of the extra material between the interface result in an increased coefficient of friction up to $200 \mathrm{~s}$. The decrease in $\mathrm{CoF}$ can be attributed to chain scission of the binders due to frictional heating, leading to decrease in their ability to join the additive together as the friction induced heat increased. Since the friction material with high coefficient of friction is a very good substitute for the production of brake-pads. Good friction property of the developed composite brake pad up to $200 \mathrm{~s}$ is an affirmation that composite mix of epoxy, hardener, gum Arabic, aluminium, graphite, ceramic clay and bentonite is a good subsitute for prodction of asbestos free brake pad through improvement on conventional casting method and optimisation of the additive composition.

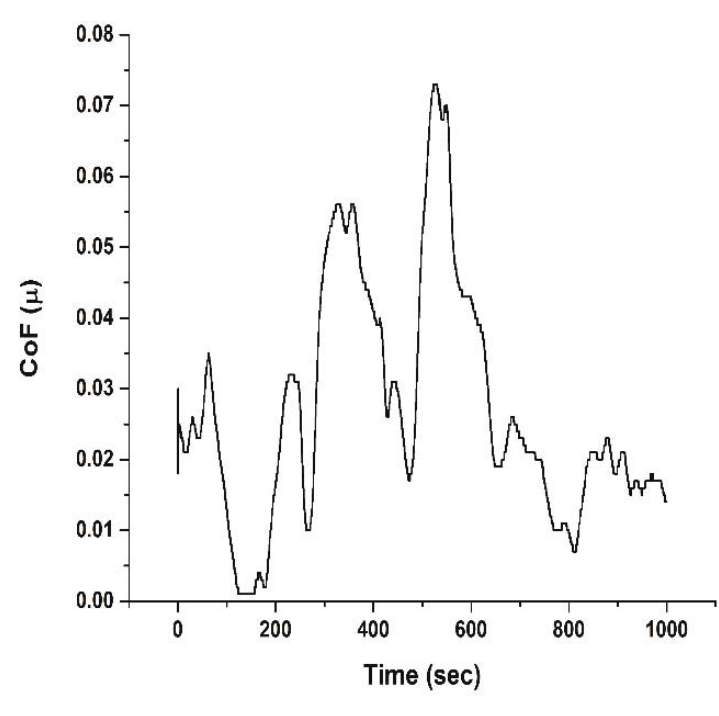

(a)

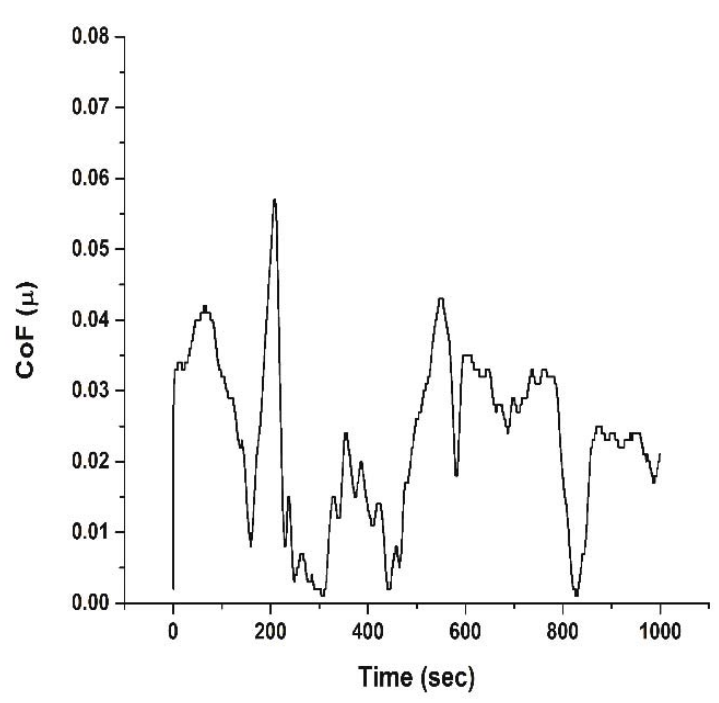

(b)

Figure 2: Coefficient of friction against time: (a) commercial grade brake pad (b) the developed composite brake pad.

Figure 3 (a-b) compares the wear behaviour of the commercial brake pad (CP) and the developed composite brake pad (DP) under dry sliding condition, increasing time, load and rotation speed of $150 \mathrm{rpm}$. Generaly, under all the loading conditions, the wear rate of both pads increased with time. The observation shows that thermomechanical loading is a primary factor. Moreso, the developed composite brake pad showed a more stable wear rate compared to the commercial brake pad. Typically, a good brake pad should posses good friction stability and by extension wear rate over a considerable period of time [9]. Nevertheless, the developed composite brake pad showed an improved resistance to material loss under the same test conditions. The improvement may be related to good 
binding property of the epoxy and gum Arabic. Therefore, both are suitable binders for composite production for brake pad applications.

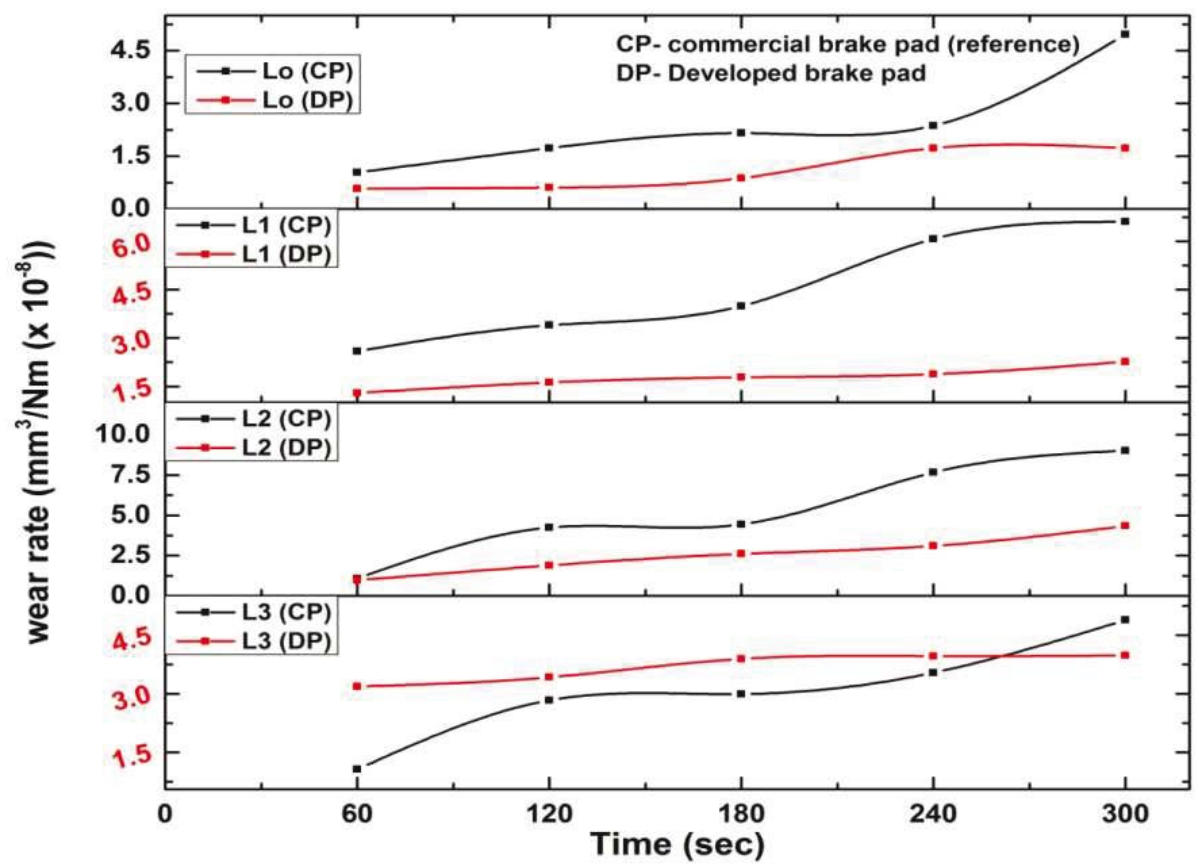

Figure 3: Matching of wear behavior of the commercial grade and the developed composite brake.

\subsection{Microstructures of the developed composite brake pad}

\subsubsection{Energy-dispersive X-ray spectroscopy of the developed compos-} ite brake pad

Plate 2 reveals microstructure and EDX spectrograph of the worn out surface of the commercial brake pad. Symbol A depicts a region of plastic deformation, symbol B shows the region of wear debris of the brake pad and symbol $\mathrm{C}$ show the fractured surface region of commercial brake pad. Presence of $\mathrm{C}, \mathrm{Ca}$ and $\mathrm{O}$ confirmed that the commercial brake pad was produced from both organic and inorganic compounds/minerals. Microstructure in Plate 3 depicts the worn out behaviour of the developed composite brake pad and non-uniform distribution of the second phase within the matrix. Symbol D reveals the epoxy which was not properly mixed with other additives. The use of mechanical shear stirring technique to aid the manual stirring is necessary to enhance the homogenity of the structure and increase the isotropy of the developed composite brake pad. Confirmed elements of the developed composite brake pads are C, O, Br and Si. 

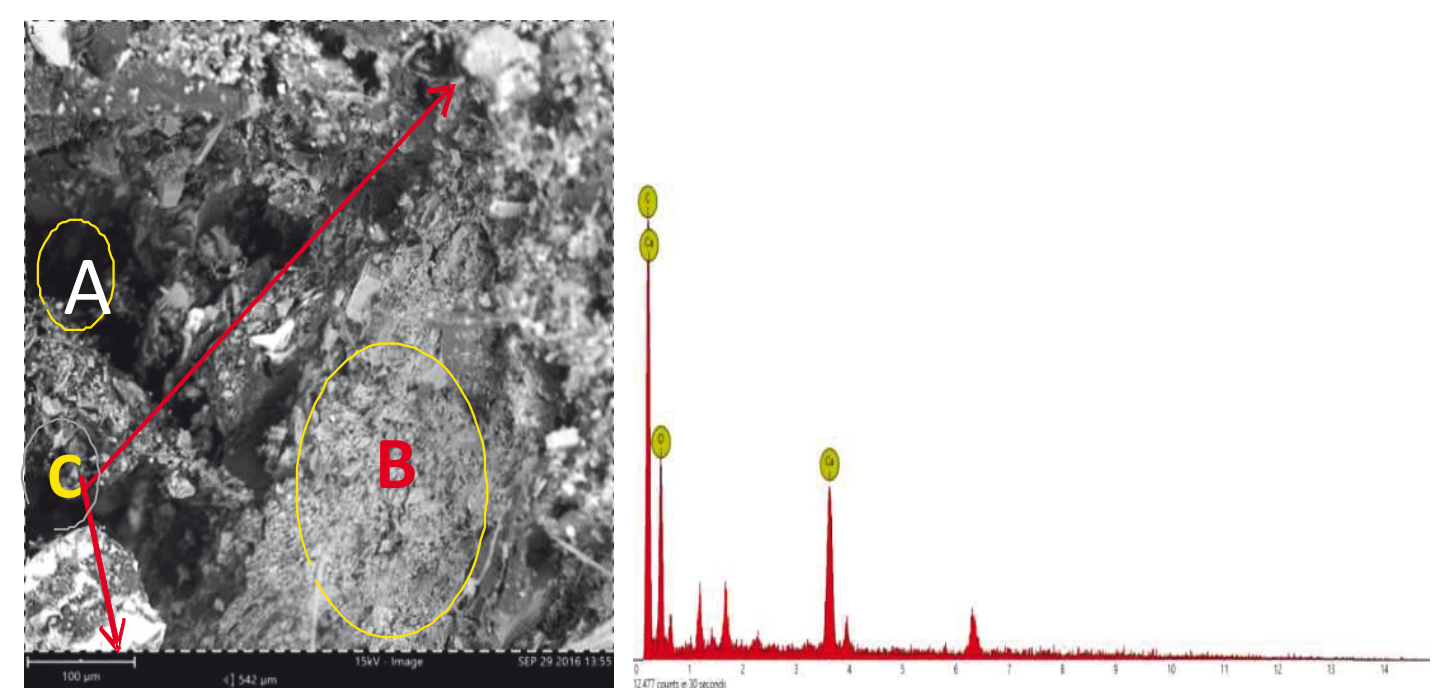

Plate 2: SEM/EDX of commercial grade brake pad.
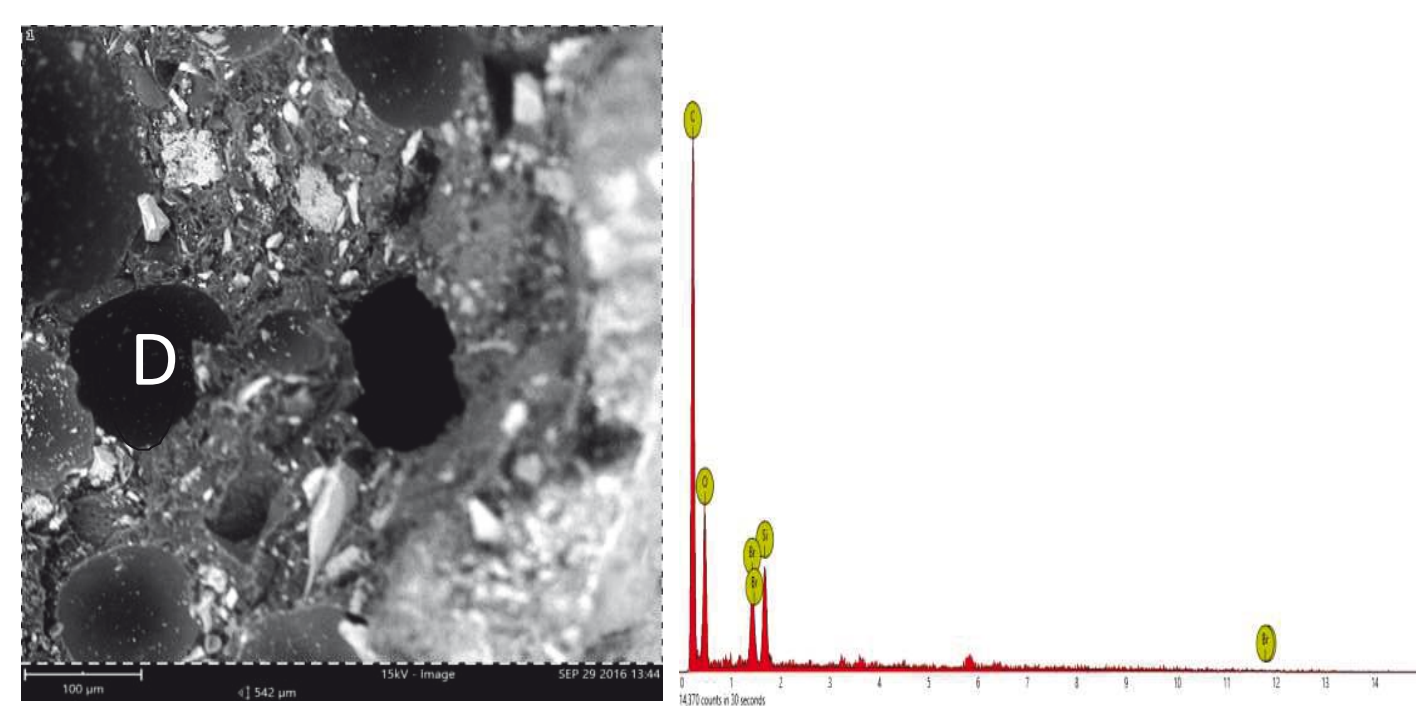

Plate 3: SEM/EDX of the developed composite brake pad. 


\subsubsection{X-Ray diffractometry of the developed composite brake pad}

The XRD profile of the commercial brake pad is presented in Figure 4a. The major peaks at 21.11, 33.312, 35.53 and $36.62^{\circ}$ shows the presence of Magnetite, syn $\left(\mathrm{Fe}_{3} \mathrm{O}_{4}\right)$, Heptadecanoic Acid $\left(\mathrm{C}_{17} \mathrm{H}_{34} \mathrm{O}_{2}\right)$, Silicon Oxide $\left(\mathrm{SiO}_{2}\right)$ and Hercynite, syn $\left(\mathrm{FeAl}_{2} \mathrm{O}_{4}\right)$, respectively. The score count of each of the phases is presented in Table 2. Figure 4b show the phases of the developed brake pad with their corresponding peaks. The count score and chemical formula of the compounds is presented in Table 3. Comparison of XRD profiles of the developed composite brake pad with those of the commercial grade shows that the phases of the developed composite brake pad were completely different from those detected in the commercial brake pad due to the discrepancies in materials of which they were made. Correspondingly, this justifies variations in their behaviour under the same test conditions.


Figure 4: XRD of: (a) commercial grade brake pad (b) cast epoxy resin based brake pad.

Table 2: Compounds present in the commercial grade brake pad.

\begin{tabular}{ccc}
\hline \hline SCORE & COMPOUND NAME & CHEMICAL FORMULA \\
\hline 41 & Magnetite, syn & $\mathrm{Fe}_{3} \mathrm{O}_{4}$ \\
27 & Heptadecanoic Acid & $\mathrm{C}_{17} \mathrm{H}_{34} \mathrm{O}_{2}$ \\
29 & Silicon Oxide & $\mathrm{SiO}_{2}$ \\
24 & Hercynite, syn & $\mathrm{FeAl}_{2} \mathrm{O}_{4}$ \\
\hline \hline
\end{tabular}

\subsection{Thermal properties}

The thermogravimetric (TG) curves in Figure 5 describe the thermal behaviour and stability of the commercial grade and the developed composite brake-pad. Both TG profiles are characterised by step-wise degradation profiles. The initial oxidation resulting in about $7 \%$ mass loss occurs below $\sim 100^{\circ} \mathrm{C}$. This mass loss can be associated with the formation of volatiles during firing. Continued heating above $\sim 400^{\circ} \mathrm{C}$ led to the formation and oxidation of carbon. However, the developed composite brake pad shows a slightly better stability to degradation in an oxidising environment compared to the commercial grade. 
Table 3: Phases of the developed composite brake pad.

\begin{tabular}{ccc}
\hline \hline SCORE & COMPOUND NAME & CHEMICAL FORMULA \\
\hline 57 & n-Nonacosane & $\mathrm{C}_{29} \mathrm{H}_{60}$ \\
40 & Hematite & $\mathrm{Fe}_{2} \mathrm{O}_{3}$ \\
23 & Nacrite & $\mathrm{Al}_{2} \mathrm{Si}_{2} \mathrm{O}_{5}(\mathrm{H})_{4}$ \\
24 & Lignite & $\mathrm{C}$ \\
\hline \hline
\end{tabular}

The residual mass of $\mathrm{CP}$ was $68 \%$ compared to the developed composite brake pad which is $72 \%$ after heating to $1000^{\circ} \mathrm{C}$. The improved overall stability can be connected to the reinforcing additives. From Figure 5b, it can be seen that maximum degradation occurs at 100,400 and $700^{\circ} \mathrm{C}$. Although TG curves have shown better thermal stability of the developed composite than the commercial grade, ability of the developed composite brake pad to sustain the thermal stability under abrasion process beyond $200 \mathrm{~s}$ is lower than that of the commercial grade brake pad. Moreover, the optimum combination of resistance to abrasion/wear and thermal stability is the prerequisite for distinctive performance of a material for brake pad application. Inability of the developed composite brake pad to retain its better friction property beyond $200 \mathrm{~s}$ limits its good performance for brake pad application. Since brake application while driving is a short span process $(<3$ minutes), the developed composite could serve as a replacement for asbestos brake pad for automobile applications.
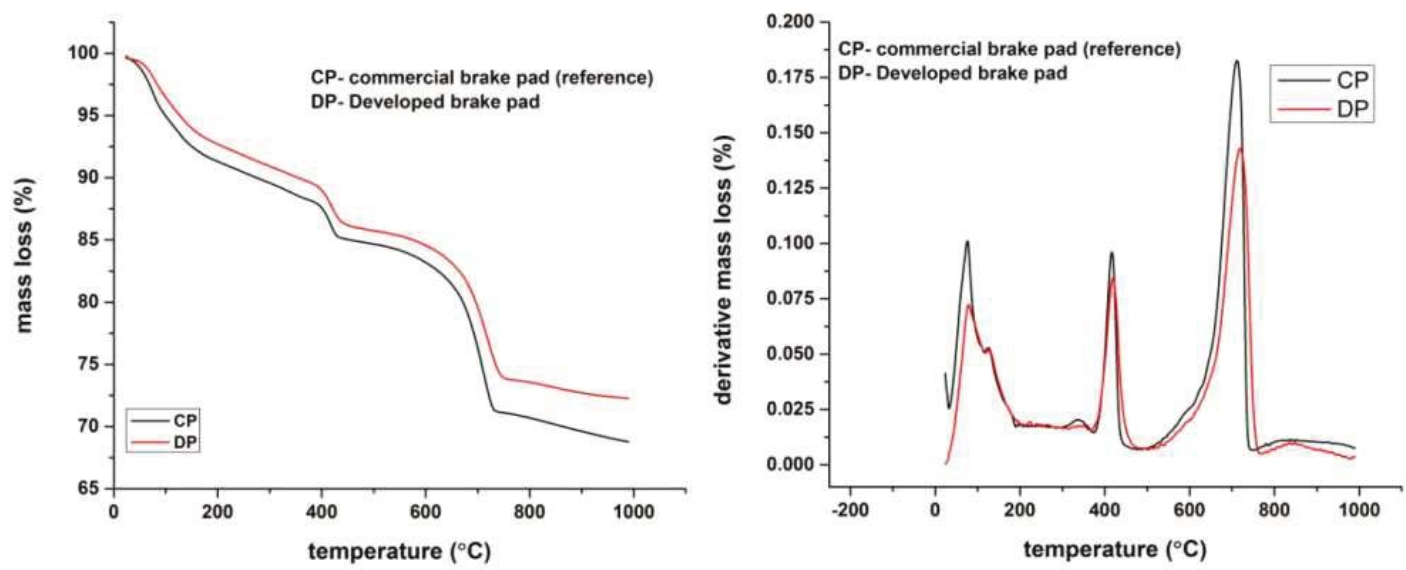

Figure 5: Matching of thermogravimetry of the commercial brake pad and the developed composite brake pad.

\section{Summary and conclusion}

An asbestos free brake pad was developed from recycled clay tiles, epoxy resin/hardener, gum Arabic, graphite and foundry slag using casting method. Results of investigation of the developed composite brake pad were compared with those of the imported brake pads bought in Nigeria. Comparison of results revealed a fair suitability of the developed composite for automobile brake pad applications. Moreover, the properties of the developed 
epoxy composite for brake pad application can be improved by adoption of combined casting and compaction technique prior to full curing of the epoxy used as a binder for other additives in the development of the composite brake pad.

\section{Acknowledgments}

Authors express their gratitude to the Department of Metallurgical and Materials Engineering, University of Lagos, Nigeria; Department of Mechanical Engineering, Redeemer's University, Ogun State Nigeria and Department of Chemical and Metallurgical Engineering, Tshwane University, Pretoria South Africa for permission to access their laboratories for the experimentation of this study.

\section{References}

[1] Blau, P.J. Compositions, Functions, and Testing of Friction Brake Materials and Their Additives. United States: N. p., 2001. Web. doi:10.2172/788356.

[2] Kim, S.J., K.S. Kim, and H. Jang, Optimization of manufacturing parameters for brake lining using taguchi method. Journal of Material Processing Technology, 2003. 136: p. 202-208.

[3] Fulvio, A., et al., Mineralogy and Elemental Composition of Brake Pads of Common Use in Spain. 2012: Spain.

[4] Mathur, R.B., P. Thiyagarajan, and T.L. Dhami, Controlling the Hardness and Tribological Behavior of Non-asbestos Brake Lining Materials for Automobiles. Journal of Carbon Science, 2004. 5(1): p. 6-11.

[5] Bashar, D., M.B. Peter, and M. Joseph, Material Selection and Production of a Coldworked Composite Brake Pad. World Journal of Engineering and Pure and Applied Science (WJEPAS), 2012. 2(3): p. 96.

[6] Ibhadode, A.O.A. and I.M. Dagwa, Development of asbestos-free friction lining material from palm kernel shell Journal of the Brazilian Society of Mechanical Sciences and Engineering (J. Braz. Soc. Mech. Sci. \& Eng), 2008. 30(2).

[7] Ishidi, E.Y., E.G. Kolawole, and K.O. Sunmonu, Morphology and thermal property of alkaline treated palm kernel nut shell HDPE composite. Journal of Emerging Trends in Engineering and Applied Sciences (JETEAS), 2011. 2(2): p. 346-350.

[8] Yawas, D.S., S.Y. Aku, and S.G. Amaren, Morphology and properties of periwinkle shell asbestos-free brake pad. Journal of King Saud University - Engineering Sciences, 2016. 28(1): p. 103-109.

[9] Idris, U.D., et al., Eco-friendly asbestos free brake-pad: Using banana peels. Journal of King Saud University - Engineering Sciences, 2015. 27(2): p. 185-192. 
[10] Ademoh, A.N. and I.O. Adeyemi, Development and Evaluation of Maize Husks (Asbestos-Free) Based Brake Pad. International Institute for Science, Technology and Education (IISTE): Industrial Engineering Letters -IEL, 2015. 5(2): p. 67-80.

[11] Das, B.S., P.S.R. Prakash, and V.N.M. Reddy, An overview of utilization of slag and sludge from steel industries Resources, . Conservation and Recycling, 2007. 50(1): p. 40-57.

[12] Umamaheswara, R.R. and R. Babji, A Review Paper on Alternate Materials For Asbestos Brake Pads and its Characterization. International Research Journal of Engineering and Technology (IRJET), 2015. 2(2).

[13] Ruzaidi, C.M., et al. Morphology and Wear Properties of Palm Ash and PCB Waste Brake Pad in International Conference on Asia Agriculture and Animal. 2011. IPCEE.

[14] Hassan, S.B., J.O. Agunsoye, and S.A. Bello, Ball Milling Synthesis of Al (1050) Particles: Morphological Study and Particle Size Determination. Industrial Engineering Letters, 2015. 5(11): p. 22-27.

[15] Peters, S.T., Handbook of Composites. 2nd ed, ed. S.T. Peters. 1998, England: Springer Science+Business Media Donlrecht. 1135. 